\title{
Sosiaalinen media ammatillisessa opetuksessa
}

\section{- ammatillisten opettajakorkeakoulujen opettajaopiskelijoiden opetuskäytänteitä}

\author{
JUKKA NIINIMÄKI \& TIIU TENNO
}

\begin{abstract}
Artikkelissa kuvataan, millaisia sosiaalisen median opetussovelluksia opettajaopiskelijat suunnittelivat viiden ammatillisen opettajakorkeakoulun yhteisen valinnaisen opintojakson "Sosiaalinen media ammatillisessa opetuksessa" aikana. Opettajaopiskelijat opiskelivat sosiaalisen median opetuskäyttöä sosiaalisen median ympäristössä syyskuusta 2008 helmikuuhun 2009 ja selvittivät, miten sosiaalista mediaa voidaan hyödyntää ammatillisen opettajan työssä.
\end{abstract}

\begin{abstract}
Treto ietoverkkoteknologian myötä on tullut mahdolliseksi suunnitella aiempaa laajempia sosiaaliseen vuorovaikutukseen perustuvia verkko-oppimisympäristöjä. Sosiaalisen median (Web 2.0) tarjoamia verkkotyöskentelyvälineitä ovat internetin ilmaiset ja kaupalliset vuorovaikutteiset mediat. Tähän kuuluvat esimerkiksi blogit ja wikit, erilaiset ääni-, kuva- ja videoaineistojen jakelupalvelut kuten YouTube tai Flickr sekä erilaiset verkkoyhteisöt kuten Facebook, Ning, Grou.ps ja Second Life virtuaalimaailma. Näistä palveluista voidaan koota oppimisympäristö, jolloin kyse on sosiaalisen median opetuskäytöstä. Sosiaalisen median käyttö voi edistää dialogia opiskelijoiden kesken sekä opiskelijoiden ja opettajan välillä ja tukea opiskelijoiden omaehtoista oppimisprosessia. Sosiaalisen median konteksti luo entistä paremmat edellytykset yhteisölliselle tiedonrakentelulle ja asiantuntijuuden kehittymiselle.
\end{abstract}

\section{Sosiaalinen media ja oppiminen}

Web 2.0:n tunnusmerkkejä ovat dynaamiset sisällöt, sosiaalisuus ja vuorovaikutus. Sosiaalinen median käytöllä ohjausvälineenä tarkoitetaan tässä sosiaalisen median pedagogista soveltamista niin välinenä kuin toimintamallina. Sosiaalista mediaa voidaan tarkastella myös pelkästään tekni- sestä näkökulmasta, jolloin kyse on työvälineestä ja sen ominaisuuksista. Toiminnallisesti sosiaalinen media tarkoittaa yhdessä toteutetun ja kaikille jaetun mediasisällön käyttämistä. Silloin sosiaalinen media voidaan nähdä sisällöntuotannon prosessina, varastona ja jakelukanavana.

Sosiaalisen median opetuskäytössä on useimmiten kyse siitä, että ohjaaja suunnittelee ja rakentaa verkko-oppimisympäristön erilaisista ilmaisista verkkopalveluista. Sosiaalinen media välineenä ja sisältönä mahdollistaa käyttäjilleen ympäristön, joka on avoin, yhteisöllinen ja vuorovaikutteinen. Kaikki voivat olla samalla sisällön tuottajia ja sisällön käyttäjiä, opettajia ja opiskelijoita. Sosiaalinen media avaakin uudenlaisen toimintakulttuurin ja käsitemaailman, jonka haltuunottaminen vie oman aikansa. Opettajan näkökulmasta tarkasteluna sosiaalinen media ja sen periaatteita toteuttava opetus vaatii melko paljon uudelleen orientoitumista. Sosiaalisen median olemassaoloa ei voida ohittaa myöskään ammatillisessa opettajankoulutuksessa.

Oppiminen Web 2.0 -ympäristössä voidaan ymmärtää verkostoissa tapahtuvana yhteisöllisenä tiedonrakenteluna. Tutkimustulosten mukaan verkkoteknologia voi ylläpitää vuoropuhelua, toimia yhteisön kollektiivisena muistina, työskentelyteorian tallentajana ja progressiivisen ongelman- 


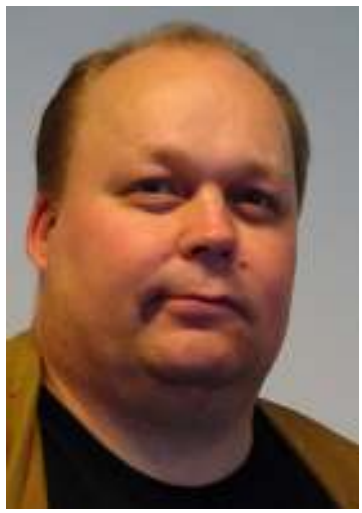

Jukka Niinimäki

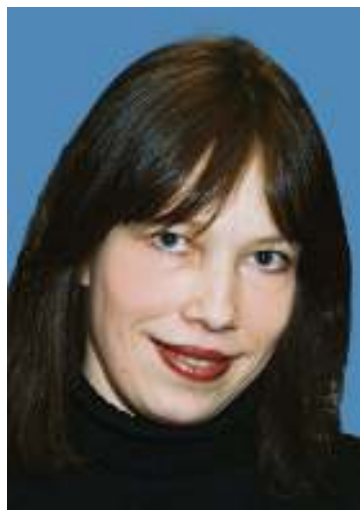

Tiiu Tenno ratkaisun tukena (Häkkinen 2004). Verkko-opetuksessa viime vuosina käytetyt pedagogiset mallit, menetelmät ja työtavat ovat pitkälti tukeutuneet sosiokonstruktivistiseen tai sosiokulttuuriseen oppimiskäsitykseen. Pedagogiikassa sosiokonstruktivismi merkitsee sosiaalisen vuorovaikutuksen korostamista, yhteistoiminnassa oppimista, keskustelua, merkityksistä neuvottelua sekä merkitysten rakentamista käytännöllisissä yhteyksissä. Sosiokonstruktivistinen painotus ilmenee opiskelussa ja opetuksessa ajatuksena uuden tiedon muotoutumisesta sosiaalisena toimintana (Lave \& Wenger 1991; Tynjälä 1999, 162-163). "Minkä oppija osaa tehdä tänään yhteistyössä, hän osaa tehdä huomenna yksin" (Kauppila 2007, 80).

Web 2.0 -välineitä ei ole tietoisesti suunniteltu pedagogisista lähtökohdista ja tukemaan oppimista. Kuten verkko-opetuksessakin, valintoja tehdessä on tärkeämpi, miten työvälineitä käytetään, kuin mitkä työvälineet ovat kyseessä. Sosiaaliseen mediaan perustuvan opintojakson suunnittelussa voi nojautua yleisiin verkko-opetuksen suunnittelun perusperiaatteisiin (Nichols 2003, 1-10), yhteisöllisen oppimisen periaatteisiin (Dillenbourg 1999; Häkkinen 2004; Häkkinen, Arvaja, \& Mäkitalo 2004), tiedonrakentelun perusperiaatteisiin tietoverkkokontekstissa (Scardamalia \& Bereiter 1996; Tynjälä 1999) ja verkkoopettamisen pedagogiikkaan (Ertmer 2005; Manninen 2001).

\section{Tutkimus ja sen taustaa}

Tutkimuksen kontekstina on viiden opettajakorkeakoulun yhteinen opintojakso ja toisaalta Web 2.0 -ympäristö. Tämä artikkeli perustuu opintojaksolla "Sosiaalinen media ammatillisessa opetuksessa" koottuun opiskelijapalautteeseen ja opiskelijoiden pohdintoihin reflektiopäiväkirjoissaan. Opintojaksolla opettajaopiskelijat tutustuivat so- siaalisen median ohjausvälineisiin ja suunnittelivat sekä toteuttivat oman opintokokonaisuuden. Tutkijoiden tavoitteena oli kuvata, millaisia sosiaalisen median ohjauksellisia ratkaisuja opettajaopiskelijat suunnittelivat ja millaisia sosiaalisen median työvälineitä he käyttivät. Opettajaopiskelijoiden omia näkemyksiä havainnollistetaan suorilla aineistolainauksilla.

Sosiaalinen media ammatillisessa opetuksessa -opintojaksolle osallistui yli 70 opettajaopiskelijaa ja seitsemän ohjaajaa Haaga-Helian, Hämeenlinnan, Jyväskylän, Oulun ja Tampereen ammatillisista opettajakorkeakouluista. Kaikki koulutusalat olivat edustettuna. Se loi hyvän pohjan opettajaopiskelijoiden työskentelylle ammattialakohtaisissa ryhmissä. Kolmannes opintojaksolle osallistuneista oli tekniikan ja liikenteen alalta. Ammattikorkeakoulujen, ammatillisen aikuiskoulutuksen ja ammatillisten oppilaitosten opettajat olivat edustettuna melko tasapuolisesti. 73 prosenttia osallistujista oli opetustehtävissä ja 64 prosenttia heistä toimi päätoimisena opettajana. Heidän opetuskokemuksensa oli pääosin lyhyt. Tosin viidennes opettajaopiskelijoista ilmoitti olleensa opetustehtävissä 4-9 vuotta. Opettajaopiskelijoilla oli vähäinen kokemus niin verkko-opetuksesta kuin sosiaalisen median opetuskäytöstä. Sosiaalisen median käsite oli ennen opintojaksolle osallistumista vieras puolelle opettajaopiskelijoista. Yli puolet oli vailla kokemusta verkko-opetuksesta. Vain kuusi prosenttia opetustyössä olevista ilmoitti heillä olevan paljon kokemusta verkko-opettajan työstä.

Opintojakson ohjausratkaisuilla pyrittiin välittämään opettajaopiskelijoille sosiaalisen median opetuskäytön hyviä käytänteitä. Ohjaustyövälineinä opintojaksolla käytettiin Ning-verkkoyhteisöä (smaope.ning.com) ja Wetpaint-wikiä (smaope.wetpaint.com). Opettajaopiskelijoiden oppimisprosessi strukturoitiin kymmeneksi oppimistehtäväksi, jotka koottiin neljäksi vaiheeksi. Tuloksellinen vuorovaikutus ei tapahdu verkossa itsestään, vaan sen aikaansaamiseksi yhteisöllistä työskentelyä tuettiin pedagogisen vaiheistamisen avulla. Opintojakson pedagoginen vaiheistus pohjautui ongelmalähtöisen ja tutkivan oppimisen malliin. Ensimmäisessä vaiheessa opettajaopiskelijat toimivat yhtenä suurena verkkoyhteisönä pohtien case-tapauksien pohjalta sosiaalisen median tietosuoja- sekä tekijänoikeuskysymyksiä. Toisessa vaiheessa opettajaopiskelijat jakaantuivat ammattialakohtaisiin pienryhmiin, jolloin eri opettajakorkeakoulujen opiskelijat sekoittuivat 
keskenään. Pienryhmät tutustuivat virikemateriaalina sosiaalisen median case-tapauksiin sekä erilaisiin sosiaalisen median tarjoamiin ohjausvälineisiin. Sen jälkeen he pohtivat wikissä pedagogisesti toimivan oppimisprosessin suunnittelua kyseisten ohjausvälineiden avulla. Opiskelijat laativat yksin, pareina tai pienryhmässä sosiaalisen median opetus- tai ohjauskokonaisuuden toteutussuunnitelman. Kolmannessa vaiheessa opiskelijat toteuttivat suunnitelmansa sosiaalisen median tarjoamilla ohjausvälineillä ja neljännessä vaiheessa tuotokset arvioitiin pienryhmissä. Opiskelijat kirjoittivat saamansa palautteen pohjalta itsearvioinnin blogiinsa.

Opintojakson ohjaus ja tiedotus toimivat Ningin ryhmäfoorumeiden ja sisäisen sähköpostin avulla. Lisäksi ohjaajat käyttivät sähköpostia. Opintojakson alussa ohjaajat pitivät joko aloituslähijakson tai reaaliaikaisen pienryhmäistunnon siihen tarkoitetuilla verkkotyövälineillä. Osa ohjaajista piti reaaliaikaisia palaute- ja arviointipalavereja, osa ohjaajista taas antoi palautetta asynkronisesti wikiin tai opiskelijoiden blogiin sekä yksilöllistä ohjausta sähköpostilla tai puhelimella. Henkilökohtaista palautetta ohjaajat antoivat opettajaopiskelijoiden suunnitelmiin ja toteutuksiin.

\section{Sosiaalisen median ohjausvälineet opiskelijoiden omissa toteutuksissa}

Opettajaopiskelijat suunnittelivat ja toteuttivat pääsääntöisesti 1-3 opintopisteen laajuisia opintokokonaisuuksia ammatillisen koulutuksen eri aloille. He hyödynsivät omissa toteutuksissaan sosiaalisen median työvälineitä monipuolisesti. Osa opiskelijoiden suunnitelmista soveltui toteutettavaksi täysin verkossa, osa monimuoto-opiskelun tai lähiopetuksen tukena. Monet suunnitelmista toteutuivat myös käytännössä. Osa toteutuksista suojattiin tietosuojasyistä salasanalla.

Opettajaopiskelijat katsoivat sosiaalisen median ohjausvälineiden soveltuvan hyvin tai erinomaisesti niin ammatilliseen opetukseen, verkostoitumiseen kuin muuhunkin oppilaitoksen henkilöstön yhteistyöskentelyyn. Parissa toteutuksessa kyse oli oppilaitoksen muuta opetusta tukevasta sosiaalisen median ohjaussovelluksesta, kuten työpaikkarekrytoinnin ohjauksesta opintojen päättymisvaiheessa. Sivutoimisilla tuntiopettajilla ei aina ole mahdollisuutta hyödyntää oppilaitosten järjestelmiä. Etenkin heille sosiaalisen median työvälineillä oli käytännön tarve.
Ohjauksessa reaaliaikaiset viestintävälineet, kuten Skype, tai kaupalliset järjestelmät, kuten WebEx tai Adobe Connect Pro, olivat usein apuna. Myös ryhmäsähköpostiviestejä sovellettiin ohjauksessa.

Sosiaalisen median ohjausvälineitä hyödynnettiin opetuksessa lähinnä kolmella tavalla: (1) oppimisprosessi rakennettiin yhden työvälineen ympärille; (2) sosiaalisen median ohjausvälineitä käytettiin verkko-oppimisympäristön rinnalla; tai (3) useita sosiaalisen median ohjausvälineitä käytettiin yhdessä.

Yhden työvälineen ympärille rakennetussa oppimisprosessissa työvälineenä saattoi olla blogi tai wiki. Blogeista etenkin Wordpress ja Googlen Bloggeri olivat helppokäyttöisyytensä vuoksi suosittuja ja ne mahdollistavat myös salasanalla suojattujen sivujen luomisen. Wiki-ympäristöistä suosittiin Wetpaintia, joka tuli opiskelijoille tutuksi opintojaksomme työskentelyalueena. Toinen suosittu wiki oli BF, joka sisältää monipuoliset ominaisuudet ryhmätyön tekemiseksi. Blogit listaavat havainnollisesti viimeisimmät tapahtumat ja soveltuvat hyvin oppimispäiväkirjan pitämiseen. Niitä voidaan käyttää julkaisemiseen vuorovaikutteisten kotisivujen tapaan.

Opettajaopiskelijoiden työvälinevalinnoissa näkyivät muun muassa Downesin (2004, 14-26) blogien opetuskäytön luokittelut, jonka mukaan blogi joko (1) korvaa kurssin verkkosivun, (2) toimii materiaalien keräämispaikkana mm. linkittämällä olemassa oleva aineistoa, (3) toimii vuorovaikutuskanavana, (4) toimii yhteisön työskentely-ympäristönä tai (6) blogin kirjoittaminen kuuluu kurssisuoritukseen. Samaa jaottelua voidaan soveltaa wikinkin suhteen. Wikeillä on mahdollista hallita laajoja kokonaisuuksia ja opiskelijoiden seurannassa helpottaa kirjoitusten sivukohtainen versiohistoria, josta näkyy tieto tekstin kirjoittajasta.

"Vesirakentamisen opintojaksolla" wikin käytettiin pedagogisesti onnistuneesti opiskelijaryhmän yhteisöllisenä työskentely-ympäristönä. Kolmen oppilaitoksen opiskelijat suorittavat yhteistoiminnallisesti kahden opintopisteen laajuisen osan isommasta kokonaisuudesta. Wiki-ympäristöstä löytyivät tarvittavat toimintaohjeet, materiaali ja ryhmien työskentelyalue. Itseopiskeluun toteutettua "Lääkehoidon blogia" taas hyödynnettiin materiaalien keräämispaikkana.

Monet opettajaopiskelijat rakensivat toteutuksensa verkko-yhteisöjen hallinta-alustoille, koska ne tarjoavat verkko-oppimisympäristöjen tapaan 
useita ohjaustyövälineitä samalla kertaa. Erityisesti Ningiä suosittiin helppokäyttöisyytensä ja suomenkielisyyden johdosta. Wiki-työvälineen puuttuminen harmitti tosin monia ja näin Ningiin täytyi usein linkittää jokin wiki. Myös Facebookia ja Grou.ps -palvelua hyödynnettiin ohjaustyövälineenä. Verkkoyhteisöä käyttäen toteutettiin mm. opiskelijoita kesätyöpaikan haussa ja urasuunnittelussa auttava sovellus "Kesä vuokralla!"

Sosiaalisen median ohjausvälineiden hyödyntäminen verkko-oppimisympäristön rinnalla oli myös melko yleistä. Osa opettajaopiskelijoista toteutti oppimisprosessin ja ohjauksen oppilaitosten verkko-oppimisympäristöissä Moodlessa, Blackboardissa, Pedanetissä tai Optimassa. Sosiaalisen median ohjausvälineitä linkitettiin verkkoympäristöön yksittäisissä oppimistilanteissa, kun verkko-oppimisympäristön omat välineet kyseiseen tarpeeseen olivat kankeita tai puuttuivat kokonaan. Moodlea ei nähty täysin erillisenä sosiaalisen median työvälineistä, koska useimmissa oppilaitoksissa se voidaan avata avoimeksi ympäristöksi.

Opettajaopiskelijat perustelivat verkko-oppimisympäristöjen käyttämistä paremmin kehittyneillä opettajan hallintatyövälineillä sekä turvallisemmilla tietosuojakäytänteillä. Monet opetustyössä olevat ovat tottuneet käyttämään edellä mainittuja verkko-oppimisympäristöjä ja ne olivat tuttuja myös opiskelijoille. Lisäksi mainittiin, että ilmaispalveluiden käyttö on epävarmempaa teknisen tuen tai vastuuhenkilön puutteen takia. Opettajaopiskelijoiden mielestä sosiaalisen median ohjausvälineet täydensivät kuitenkin varsin toimivalla tavalla verkko-oppimisympäristöjä. Toteutuksissa yhdistettiin esimerkiksi BlackBoard, WebEx ja Mind Map tai Optima, Wiki, Blogger ja Ning.

Usean erilaisen sosiaalisen median ohjausvälineen käyttö eri oppimistilanteissa monipuolisti oppimisprosessia. Toisaalta kyse saattoi olla vain yhden oppimistehtävän toteuttamisesta verkossa lähiopetuksen tukena, kuten rikosoikeuden roolipelissä Ning-verkkoyhteisössä lakitiedon opintojaksolla. "Teknillisen piirtämisen perusteet" -kurssilla taas hyödynnettiin onnistuneesti useita työvälineitä ja palveluita. Tällaista opintojakson suunnittelua kuvaa parhaiten ns. tähtimalli, missä yhteen seurantasivuna käytettävään työvälineeseen liittyy useita eri ohjausvälineitä (vrt. Pönkä 2007; Impiö \& Pönkä 2008). Esimerkiksi Wiki toimi opetuksen runkona, johon linkittyi Google Docsista, You tubesta sekä Del.icuo.us oppimateriaalia ja reaaliaikaisina ohjausvälineinä toimivat Skype ja Webex. "Palaveritekniikat virtuaaliympäristöissä" -kurssilla taas hyödynnettiin keskeisenä ohjaustyövälineenä Ningiä ja reaaliaikaisina työvälineinä Second Lifea ja Skypeä. Monen ohjausvälineen yhtäaikainen käyttö edellyttää tarkkaa ohjeistusta ja riittävän selkeää työvälineiden linkittämistä keskenään.

\section{Sosiaalisen median hyödyntämisestä ammatillisessa opetuksessa}

Leinosen väitöskirjatutkimus $(2008,159)$ ammatillisen opettajan verkkotaidoista osoittaa, että opettajilla, jotka olivat prosessoineet omaa pedagogista ajatteluaan, toiminta johti käsitteelliseen muutokseen ja uudistuneeseen opettajuuteen. Sosiaalinen media ammatillisessa opetuksessa -opintojakson blogikirjoituksista ilmeni, että etenkin opettajaopiskelijat, joilla oli opetuskokemusta, osasivat hienosti suunnitella ja arvioida pedagogisesta näkökulmasta sosiaalisen median ohjausvälineiden käyttöä omissa toteutuksissaan.

Opettajaopiskelijoiden suunnittelemia sosiaalisen median opintokokonaisuuksia tarkasteltiin verkko-oppimisen yleisten suunnitteluperiaatteiden mukaisesti aikaisemmin mainitussa teoreettisessa viitekehyksessä. Erityistä huomiota kiinnitettiin siihen, miten he ovat suunnitelleet yksilöiden ja ryhmien oppimisprosessin ja sen ohjauksen. Tarkastelu pohjautuu opettajaopiskelijoiden reflektioihin blogeissaan.

\section{Työvälineiden hyöty ja haaste}

Käytännön ratkaisuissa on keskeistä valittujen sosiaalisen median elementtien linkittyminen toisiinsa. Niiden elementtien on myös muodostettava ajallisesti ehjä jatkumo. Välinevalintoja katsomatta oppimisprosessin takaa vain asianmukainen ohjaus. Opettajaopiskelijat ymmärsivät, että kyse ei ole vain perinteisen opetuksen siirtämisestä Web 2.0 -ympäristöön. Tutkimuksien mukaan opettajat suosivat pedagogisesti mielekkäällä tavalla rakennettuja teknologioita (Granger et al. 2002, 480), johon sosiaalisen median välinetarjotin ei vielä yllä. Blogikirjoituksissaan opettajaopiskelijat kokivat pääosin sosiaalisen median työvälineet helppokäyttöiseksi ja mielekkäiksi.

Toisaalta opettajaopiskelijat havaitsivat, että mitä monipuolisempi työväline, sitä vaikeampi on kokonaisuuden hallinta: 
”Työvälineitä on paljon, eikä kaikkia mahdollisia työvälineitä kannata ottaa käyttöön sekavuuden takia. Lopulta liian monimutkaiset työvälineet aiheuttaa enemmänkin tehottomuutta kuin tehokkuutta. Sosiaalinen media ei ole itseisarvo. Opettajan tulee osata valita hyvin selkeät työvälineet ja perehdyttää opiskelijoita niiden käyttöön hyvinkin rautalangasta vääntämällä."

"--sosiaaliseen mediaan voi eksyä. Virtuaaliavaruus on välillä laaja."

Opettajaopiskelijat havaitsivat oman toteutuksensa yhteydessä, että wikit ja blogit voivat olla opiskelijan seurantatyövälinenä työläitä. Opiskelijoiden suorituksia on sosiaalisen median maailmassa vaikea hallinnoida, ellei oppimisprosessia ole suunniteltu todella hyvin.

\section{Kokonaishallinta}

Monet opettajaopiskelijat käyttivät oman kurssinsa suunnittelussa mallina tämän opintojakson pedagogista toteutusta, jolloin Ning tarjosi ympäristön opintojakson hallinnoinnille ja opettajaopiskelijoiden yksilöllisille reflektointiblogeille. Ningiin linkitettyyn wikiin taas laadittiin tarkemmat toimintaohjeet, oppimistehtävät ja oppimateriaali sekä ryhmätehtävät omille wikisivuilleen. Pinnallinen suunnittelu ja nopea toteutus havaittiin sosiaalisen median ympäristössä helposti:

"Suunnitelman puutteet näkyivät myös toteutuksessa, jossa oppimisprosessi ei enää näkynytkään selkeästi. Toteutus oli yksinkertainen mutta ehkä liian perinteinen portaali, jossa opiskelijan ohjeistus ja oikealle kulkureitille ohjaaminen puuttui. Suunnitelman mukainen pedagoginen malli sirpaloitui linkkeihin."

Monet opettajaopiskelijat arvioivat, että työvälineitä oli tarjolla liian paljon, jolloin niiden ominaisuuksia ei ehditty selvittää ennen työvälineen käyttöönottamista. Oppimisprosessi saattoi muodostua sekavaksi, kun opintojaksolle otettiin liikaa ohjausvälineitä käyttöön. Vaikka pedagoginen johtoajatus oli näkyvissä, niin aina ohjausvälineiden käyttöä ei ehditty harkita.

”Ning-verkkoympäristöllä on myös taipumusta muuttua sekavaksi, mikäli materiaalia tulee paljon. Siksi pyrin pitämään sivuston mahdollisimman pelkistettynä ja selkeänä. Näin sivustoa on helpompi hallita. Sivuston raken- ne kannattaakin miettiä tarkkaan ennen kuin alkaa tekemään mitään."

Opettajan toimintaa ulottuu kaikille oppimisympäristön osa-alueille ja voi suuntautua oppimisprosessin aikana myös ennakoimattomaan suuntaan. Samonin (2004) viisiportaisessa oppimis- ja ohjausprosessin mallissa kuvataan hyvin, miten opettajan rooli siirtyy prosessin aikana teknisestä ja sosiaalisesta osaamisesta kohti pedagogista ja moniosaajan tehtävää. Monen opettajaopiskelijan verkko-opettajan taidot olivat vielä puutteellisia eikä omaa roolia verkko-oppimisprosessissa osattu suunnitella täysin.

\section{Yksilön ja ryhmän ohjaus}

Ohjaus käsittää oppimisprosessin suunnittelun, arvioinnin, palautteen, prosessin ja sisältöjen ohjauksen sekö oppimisprosessin aikaisen dialogin (Koli \& Silander 2002). Viitekehykset ohjauksen suunnittelulle asetti opettajaopiskelijan valitsema pedagoginen malli, jota hän pyrkii toteuttaman sosiaalisen median ympäristössä.

"Konstruktiivisen oppimiskäsityksen oivallinen osuminen esim. wikityöskentelyyn. ...opiskelijan suurin oppi on osata yhdistää asioita uudella tavalla ja se erityisesti toimii syventävien opintojen vaiheessa sosiaalisen median kautta. Yhtä absoluuttista totuutta ei ole vaan kyse on kulloisenkin ryhmän käsityksestä totuuden heijastumasta. Ja tässä juuri on se suuri etu!!”

Oppimisympäristöjen suunnittelussa on otettava huomioon, millainen toiminta ja oppiminen soveltuvat sosiaalisen median kontekstiin, jossa oppiminen perustuu pääsääntöisesti yhteisölliseen toimintaan. Kaikki oppimisen muodot eivät ole tehokkaita ryhmissä. Hyvien oppimisprojektien lähtökohtana pidetään yksilöllisten ja yhteisöllisten opiskelumuotojen yhdistämistä. (Häkkinen \& Arvaja 1999, 220)

Opettajaopiskelijat havaitsivat, että yhteisöllisessä verkkotyöskentelyssä opiskelijoiden toiminta kannattaa suunnitella etukäteen tarkasti. Tyypillisin opettajaopiskelijoiden tekemä virhe oli ryhmätehtävien suunnittelu kurssin alkuvaiheeseen, jolloin opiskelijat eivät ehtineet ryhmäytyä ja ryhmäytymisen ohjaus saattoi olla puutteellista. Toisaalta moni opiskelija totesi, että sosiaalista mediaa voi hyödyntää myös yksilöohjauksen välineenä esimerkiksi Ningin blogia työssäoppimisen 
ohjauksessa opiskelijan oppimispäiväkirjana.

"Jos lähikontaktia opiskelijoihin vähennetään sosiaalisen median käytön takia, voi kontakti kärsiä koska netin kautta tapahtuva yhteys ei korvaa kokonaan henkilökohtaista yhteyttä... ryhmäytyminen on haasteellisempaa. Syrjäytyminen ja aikatauluista luistaminen saattaa olla helpompaa ilman lähikontaktia. Täytyy pyrkiä löytämään sopiva balanssi aina kunkin opetettavan asian kohdalla henkilökohtaisen kontaktin ja verkon välityksellä tapahtuvan välillä”

Monet opettajaopiskelijat pyrkivät heti opetuksen alussa teettämään liian vaikeita ja laajoja ryhmätöitä verkossa tai ryhmätehtäviä saatettiin teettää verkossa liian paljon. Tällöin opiskelijoiden taidot ja aika eivät riittäneet niiden tekemiseen. Osa opettajaopiskelijoista havaitsi itse, ettei heidän verkkoon laatimansa ohjeistus ollut riittävä. Ohjeistusta piti toteutuksen edetessä paikkailla sähköpostiviestein.

"Esim. yhteisöllisyyden hyödyt ei kaikille ole itsestään selviä. Haaste on myös saada opiskelijat oikeasti tekemään asioita yhdessä esim. wikiin. Tulee huolehtia siitä, että kaikki varmasti osallistuvat ja tuovat panoksensa."

Kokemuksen kautta opittiin, että kaikille yhteinen orientaatiovaihe joko kasvotusten tai videoneuvontajärjestelmän välitykselle on paras tapa varmistaa oppimisprosessin alkaminen. Myös aloitustoimien jälkeen opiskelijoille täytyy tarjota ohjeita ja malleja eli käsikirjoitus, jonka perusteella opintojaksolla edetään. Riittävä ohjeistus auttaa hahmottamaan kokonaisuuden rakenteen ja laajuuden sekä suunnittelemaan ajankäyttöä.

\section{Oppimateriaali}

Sosiokonstruktivismin hengessä opettajaopiskelijat oivalsivat, että opiskelija toimii sisällön ja oppimateriaalin tuottajana. Suunnittelussa tähdättiin siis yhteisölliseen tiedontuottamiseen ja vähäisempään opettajan materiaalituotantoon. Opiskelijat katsoivat, että sosiaalisen median ympäristöissä on syytä hyödyntää internetin valmista oppimateriaalia, jota linkitettiin muun muassa YouTube-, Flickr- ja FileShare -palveluista.

"Sosiaalisessa mediassa mahdollistuu luovuus, joustavuus, dynaamisuus, sosiaalisuus ja monipuolisuus. Tiedotus on kaikkien saatavil- la, samoin materiaalit. Oppimista voi syventää tutkimalla asioita yhteisöllisesti ja monin eri välinein. Luovat mahdollisuudet tuottaa materiaaleja tekevät opetuksesta kiinnostavaa ja monenlaisille opiskelijoille soveltuvaa."

Oppimateriaalikeskeinen opetusmallikin nousi yhä joissakin toteutuksissa esille. Niissä kiinnitettiin enemmän huomiota omaan materiaalituotantoon kuin kurssin pedagogiseen suunnitteluun. Tekijänoikeusasiat koettiin "harmaina", mikä osaltaan selittää pyrkimyksen käyttää pelkästään omaa opetusmateriaalia. Monet olivat myös tyytyväisiä tullessaan tietoiseksi Creative Commons -lisenssistä.

\section{Loppulause}

Sosiaalinen median ammatillisessa opetuksessa opintojaksolla opettajaopiskelijat suunnittelivat omaan opetukseensa sosiaalisen median opintotai ohjauskokonaisuuden tai kehittivät muulla tavoin omia pedagogisia käytänteitään sosiaalisen median verkkoyhteisöjen ja ohjausvälineiden pohjalta. Kaikkia sosiaalisen median työvälineitä ei ehditty tarkastella, joten opettajaopiskelijat valitsivat usein käyttöönsä tuttuja työvälineitä. Muilta saatu malli oli tärkeä.

Opiskelijoiden toteutuksissa sosiaalisen median ohjausvälineitä hyödynnettiin opetuksessa monipuolisesti. Huomiota kiinnitettiin oppimisprosessin tarkkaan etukäteissuunnitteluun sekä verkko-oppimisympäristön selkeään rakenteeseen ja hyviin ohjeisiin. Monet pyrkivät rajoittamaan ohjaustyövälineiden määrällistä käyttöä. Selkeyden vuoksi opetus saatettiin suunnitella vain yhden työvälineen, kuten blogin tai wikin ympärille. Jotkut suosivat verkkoyhteisöjä, kuten Ning tai Facebook, jotka tarjoavat laajempiin opintokokonaisuuksiin useita ohjauksellisia työvälineitä. Virtuaalipalaverit koettiin tärkeäksi. Osa opettajaopiskelijoista turvautui verkko-oppimisympäristöihin, käyttäen sosiaalisen median työvälineitä tukena tarpeen mukaan. Muutamissa tapauksissa sosiaalisen median ohjausvälineitä hyödynnettiin yksittäisissä oppimistilanteissa lähiopetuksen tukena.

Opettajaopiskelijoiden ohjausnäkemyksessä painottui sosiokonstruktivistinen ajattelutapa. He näkivät opiskelijat aktiivisina uuden tiedon tuottajina, ei passiivisina oppimateriaalin hyödyntäjinä. Opettajan materiaalituotanto minimoitiin. Opettajaopiskelijoiden suunnittelema opetus perustui 
paljolti yhteisölliseen tiedontuottamiseen. Toisaalta moni opettajaopiskelija totesi, että sosiaalinen media voi olla myös toimiva yksilöohjauksen väline, eikä aina välttämättä edellytä ryhmätoimintaa.

Opintojakson jälkeen opettajaopiskelijat totesivat olevansa avoimempia sosiaalisen median ohjausvälineiden hyödyntämiseen ja uskaltavat kokeilla uusia teknisiä ratkaisuja. Vaikka omissa toteutetussa opintokokonaisuuksissa saattoi yhä olla ohjauksellisia puutteita, kaikki kokivat enemmän tai vähemmän onnistumisen iloa.

\section{Lähteet ja kirjallisuus}

Downes, S. (2004). Educational Blogging. EDUCAUSE Review, 39(5) (September/October 2004). 14-26. Viitattu 16.3.2009 http:// connect.educause.edu/Library/EDUCAUSE+ Review/EducationalBlogging/40493

Dillenbourg, P. (toim.)(1999). Collaborative learning: cognitive and computational approaches. Amsterdam: Pergamon.

Ertmer, P. (2005). Teacher Pedagogical Beliefs: The Final Frontier in Our Quest for Technology Integration? Educational Technology Research \& Development. 4, 25-39.

Granger, C. A., Morbey, M. L., Lotherington, H., Owston, R. D. \& Wideman, H. H. (2002). Factors contributing to teachers' successful implementation of IT. Journal of Computer Assisted Learning, 18(4), 480-488.

Häkkinen, P. \& Arvaja, M. (1999). Kollaboratiivinen oppiminen teknologiaympäristöissä. Teoksessa A. Eteläpelto \& P. Tynjälä (toim.), Oppiminen ja asiantuntijuus: Koulutuksen ja työelämän näkökulmia. WSOY, 206-221.

Häkkinen, P., Arvaja, M. \& Mäkitalo, K. (2004). Prerequisites for CSCL: Research approaches, methodological challenges and pedagogical development. Teoksessa K. Littleton, D. Faulkner \& D. Miell (toim.), Learning to collaborate and collaborating to learn (161175). Nova Science Publishers: New York.

Häkkinen, P. (2004). Yhteisöllisen oppimisen teoriasta perusteita verkko-oppimisen käytäntöön. Erikoisartikkeli: Oppimisen teoriasta tukea tieto- ja viestintätekniikan pedagogiseen käyttöön. Suomen virtuaaliyliopisto. Viitattu 9.1.2009 http://tievie.oulu.fi/verkkopedagogiikka/luku_1/johdanto.htm
Impiö, N. \& Pönkä, H. (2008). Develope-workshop 1, 7.11.2008. Viitattu 15.3.2009

http://www.slideshare.net/NiinaI/workshop7112008-presentation

Kauppila, R. (2007). Ihmisen tapa oppia. Johdatus sosiokonstruktivistiseen oppimiskäsitykseen. Jyväskylä: PS-kustannus.

Koli, H. \& Silander, P. (2002). Oppimisprosessin suunnittelu ja ohjaus. Hämeen ammattikorkeakoulun julkaisuja D:134. Hämeenlinna.

Korhonen, V. \& Koivisto, M. (2007). Muuttuvat oppimisympäristöt ja yliopisto-opettajan asiantuntijuus. Teoksessa V. Korhonen (toim.), Muuttuvat oppimisympäristöt yliopistoissa? Tampereen yliopistopaino Oy, 59-77.

Lave, J. \& Wenger, E. (1991). Situated Learning: Legitimate Peripheral Participation. Cambridge University Press. New York.

Leinonen, A-M. (2008). Ammatillinen opettajuus kansallisessa verkko-opetuksen kehittämishankkeessa. Akateeminen väitöskirja. Acta Universitatis Tamperensis 1325. Tampere: Tampere University Press.

Manninen, J. (2001). Verkko aikuisen oppimisympäristönä. Teoksessa: Sallila, P. \& Kalli, P. 2001. Verkot ja teknologia aikuisopiskelun tukena. Aikuiskasvatuksen 42. vuosikirja. Helsinki: Kansanvalistusseura ja Aikuiskasvatuksen Tutkimusseura.

Nichols, M. (2003). A theory for eLearning. $E d u$ cational Technology \& Society, 6(2), 1-1.

Pönkä, H. (2007). Verkko-oppimisympäristö 2.0 Viitattu 15.3.2009 http://harto.wordpress.com /2007/09/14/verkko-oppimisymparisto-20/

Samon, K. 2004. E-moderating: The Key to Teaching and Learning Online. 2 painos. London: Kogan Page.

Scardamalia, M., \& Bereiter, C. (1996). Computer support for knowledge-building communities. Teoksessa T. Koschmann (toim.), CSCL: Theory and practice of an emerging paradigm (249-268). Mahwah, New Jersey: Lawrence Erlbaum Associates.

Tynjälä, P. (1999). Konstruktivistinen oppimiskäsitys ja asiantuntijuuden edellytysten rakentaminen koulutuksessa. Teoksessa Eteläpelto \& Tynjälä (toim.) Oppiminen ja asiantuntijuus. Työelämän ja koulutuksen näkökulma, 160-179. Helsinki: WSOY 